\title{
DIFFERENCIÁLGEOMETRIA A MÉRNÖKKÉPZÉSBEN
}

\author{
Árvai-Homolya Szilvia \\ egyetemi docens, Miskolci Egyetem, Matematikai Intézet, Analizis Tanszék \\ 3515 Miskolc, Miskolc-Egyetemváros, e-mail: szilvia.homolya@uni-miskolc.hu
}

\begin{abstract}
Absztrakt
A klasszikus differenciálgeometria tárgya - tömören fogalmazva - az $\mathbb{R}^{3}$-beli görbék és felületek megfelelö differenciálhatósági feltételek elöírása mellett történö vizsgálata a differenciál- és integrálszámitás eszközeinek alkalmazásával. Mivel erösen épit a lineáris algebrai, illetve az analizisbeli ismeretekre, igy a differenciálgeometria elemei az ötéves egyetemi szintü mérnökképzés magasabb évfolyamos analizis kurzusai között jelentek meg, amelyek a bolognai rendszer bevezetését követöen szinte teljesen kiszorultak az alapképzésböl. A cikk célja betekintést nyújtani az osztatlan képzés keretében oktatott differenciálgeometriai témakörökbe, valamint néhány példát mutatni a differenciálgeometria alkalmazásaira.
\end{abstract}

Kulcsszavak: görbeelmélet, kísérö triéder, felületek, alkalmazások

\section{Abstract}

The goal of classical differential geometry is to study curves and surfaces in $\mathbb{R}^{3}$ uses the techniques of differential and integral calculus. This mathematical discipline is strongly based on knowledge of linear algebra and calculus, hence the elements of classical differential geometry appeared in advanced analysis courses in former university-level education in engineering. The implementation of the Bologna process, the admission of the two-cycle system have led almost completely to the exclusion of differential geometry from bachelor's degree programs. This paper is devoted to a short overview of the abovementioned topics and to give some applications.

Keywords: curve theory, Frenet frame, surfaces, applications

\section{Bevezetés}

A differeniálgeometria alkalmazásának egyik legismertebb példája az Einstein-féle relativitáselmélet, de a mechanikán belül is megjelenik a matematika ezen ágának felhasználása. A számítógépes grafika, illetve a számítógéppel segített geometriai tervezés szintén differenciálgeometriai alapokra épít, a digitális jelfeldolgozás területén felmerülö problémák egy része is differenciálgeometriai eszközökkel oldható meg és tovább sorolhatnánk a példákat a különböző tudományterületeken történő alkalmazhatóságról. Indokolt tehát a differenciálgeometria alapjainak megjelenítése a müszaki képzési területen is.

A klasszikus differenciálgeometria egyik kiindulópontja az a tény, hogy az elemi és az analitikus geometria eszközeivel csak az euklideszi tér speciális alakzatainak vizsgálatára nyílik lehetőség. Az analitikus geometriában az algebrai egyenletekkel leírható alakzatok geometriai tulajdonságainak tárgyalására kerül sor, az ilyen típusú görbék és felületek köre azonban igencsak korlátozott. Kizárólag az analitikus geometria eszközeit használva, további nehézséget jelent az alakzatok metrikus jellemzőinek (pl. ívhossz, felszín, térfogat) meghatározása is. A differenciálgeometria módszereivel viszont az előző problémák megoldhatóak, valamint magasabb szintủ vizsgálatok (pl. a görbék és a 
felületek görbületi jellemzése) is elvégezhetőek. [7]

A Miskolci Egyetem Gépészmérnöki Karán a korábbi ötéves mérnökképzésben - a klasszikus differenciálgeometriai témakörök közül - az $\mathbb{R}^{3}$-beli görbék elméletéből tárgyalásra került az ívhossz, a kísérö triéder, a görbület, valamint a torzió fogalma és kiszámítása, míg a felületelméletből a felületek vektoregyenletes megadása, a felületi görbék ívhossza és görbülete, az érintősík fogalma, valamint a felületdarab felszínének meghatározása épült be a haladóbb matematikai kurzusok anyagába. A "Müszaki matematikai gyakorlatok" sorozatban íródott, a témakört érintő egyetemi segédkönyv [3] jellegéből adódóan szép számmal tartalmaz - elsősorban mechanikai - alkalmazásokat.

A következökben visszatekintésként a mérnökképzés korábbi, differenciálgeometriához kapcsolódó tananyagából szemelvényezünk, majd példákat adunk a témakör alkalmazásaira.

\section{Térgörbék differenciálgeometriája}

Mechanikai szempontból térgörbe alatt egy olyan leképezést értünk, amely egy tömegpont térbeli mozgását írja le az idő függvényében, azaz a leképezés tetszőleges t időpillanathoz a mozgó tömegpont pillanatnyi helyvektorát rendeli. A leképezés képterét a görbe pályájának nevezzük, azaz a hétköznapi szóhasználattal szemben jelen esetben a görbe egy leképezést jelent és nem annak pályáját. A görbe geometriai jellemzőin a leképezésből származtatott azon adatokat értjük, amelyek csak a pálya alakjától függenek, invariánsak a görbe átparaméterezésével szemben, továbbá nem változnak meg akkor sem, ha a görbének egy térbeli izometriával nyert képét vesszük. [7]

Simán paraméterezett térgörbe (vagy röviden sima görbe) alatt egy $C^{\infty}$-osztályú

$$
\gamma: I \rightarrow \mathbb{R}^{3}
$$

leképezést értünk, melyet reguláris parametrizált térgörbének nevezünk, ha $\forall t \in I$ esetén teljesül a $\dot{\gamma}(t) \neq 0$ regularitási feltétel.

\section{1. Ívhossz}

Az $\mathbb{R}^{3}$ euklideszi térben vett folytonos $\gamma$ görbe $[a ; b] \subset I$ részintervallumra történő leszükítését rektifikálhatónak nevezzük, ha a $\left.\gamma\right|_{[a ; b]}$ görbedarabba írt közelítő poligonok (töröttvonalak) hosszának létezik a szuprémuma, azaz a pontos felső korlátja. Ekkor a görbeszegmens hosszán ezt a szuprémum értéket értjük. (1. ábra)

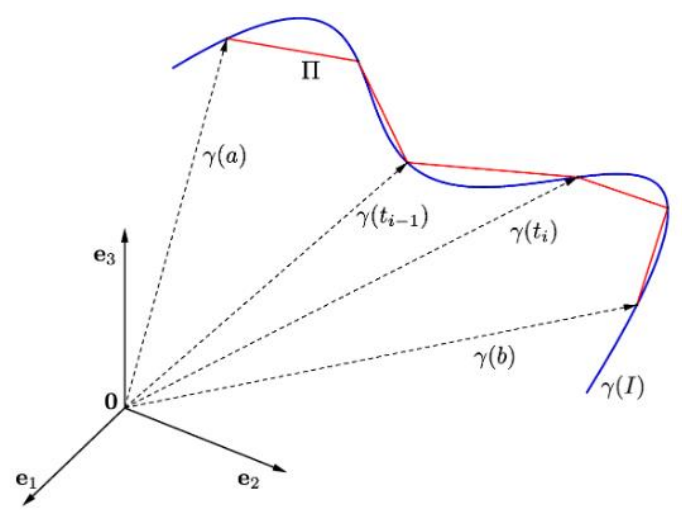

1. ábra. Közelítö poligonok 
Ugyan vannak olyan folytonos görbék, amelyek nem rektifikálhatóak, de ha egy görbe folytonosan differenciálható görbe, akkor mindig értelmezhető a görbedarab ívhossza, melynek kiszámítását a következő - az alapképzési szakok analízis kurzusaiban napjainkban is ismertetett - tétel adja meg:

1. Tétel Tetszöleges folytonosan differenciálható $\gamma: I \rightarrow \mathbb{R}^{3}$ görbe bármely $[\alpha ; \beta] \in I$ zárt intervallumhoz tartozó $\left.\gamma\right|_{[\alpha ; \beta]}$ görbedarabja rektifikálható és a görbedarab ivhossza

$$
s=\int_{\alpha}^{\beta}|\dot{\gamma}(t)| d t
$$

módon számitható ki.

Belátható, hogy az ívhossz a görbe geometriai tulajdonsága, azaz az ívhossz független a paraméterezéstől. Bizonyítható, hogy az ívhossz mindig bevezethető paraméternek. Egy $\gamma: I \rightarrow \mathbb{R}^{3}$ reguláris sima görbéről azt mondjuk, hogy ívhossz szerint van paraméterezve, ha $|\dot{\gamma}(s)|=1$ teljesül tetszőleges $s \in I$ esetén.

A $\gamma$ paraméterezésủ reguláris görbeív $t$ paraméterü pontjában a $\dot{\gamma}(t)$ érintő iránya $\mathbf{t}(t)=$ $\frac{\dot{\gamma}(t)}{|\dot{\gamma}(t)|}$, az egységnyi érintővektor. Ívhossz szerinti paraméterezés esetén

$$
\mathbf{t}(s)=\dot{\gamma}(s)
$$

Példa. Legyen $a \in \mathbb{R}^{+}$és $\mathrm{b} \neq 0 \in \mathbb{R}$. A $\gamma: \mathbb{R}^{3} \rightarrow \mathbb{R}$ görbét közönséges hengeres csavarvonalnak nevezzük, ha

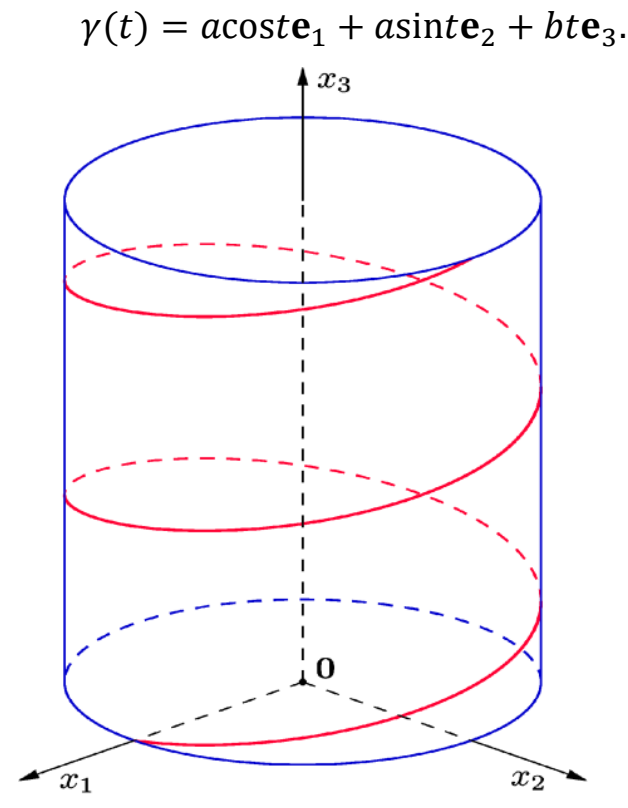

\section{2. ábra. Közönséges hengeres csavarvonal}

A $\gamma(\mathbb{R})$ pálya rajta van az $x_{1}{ }^{2}+x_{2}{ }^{2}=a^{2}$ egyenletü hengerfelületen. Amennyiben ezt egy tömegpont mozgását leíró függvénynek tekintjük, akkor az $x_{3}=0$ egyenletü síkra eső vetülete egy egyenletes körmozgást, az $x_{3}$ tengelyre eső vetülete pedig egyenletes egyenesvonalú mozgást ír le. 
A hengeres csavarvonal ívhossz-paraméteresen adott egyenlete

$$
\gamma(s)=a \cos (\delta s) \mathbf{e}_{1}+a \sin (\delta s) \mathbf{e}_{2}+b \delta s \mathbf{e}_{3},
$$

ahol $\delta=\frac{1}{\sqrt{a^{2}+b^{2}}}$. Mivel

$$
\dot{\gamma}(s)=-a \delta \sin (\delta s) \mathbf{e}_{1}+a \delta \cos (\delta s) \mathbf{e}_{2}+b \delta \mathbf{e}_{3},
$$

így

$$
|\dot{\gamma}(s)|=\sqrt{a^{2} \delta^{2} \sin ^{2}(\delta s)+a^{2} \delta^{2} \cos ^{2}(\delta s)+b^{2} \delta^{2}}=1 .
$$

\subsection{Görbület}

A differenciálgeometriában fontos szerepet játszik a görbület fogalma, képletesen szólva a görbület az érintőirány ívhossz szerinti irányváltozási sebessége a görbe egy adott pontjában.

1. Definíció. A görbe ívhossz szerinti $\gamma$ paraméterezésének $\ddot{\gamma}(s)$ második deriváltja a görbe görbületi vektora, melynek hossza

$$
\kappa(s)=|\ddot{\gamma}(s)|
$$

a görbe görbülete, iránya pedig az

$$
\mathbf{n}(s)=\frac{\ddot{\gamma}(s)}{\kappa(s)}
$$

egységnyi görbületi vektor, amelyet a görbe (fö)normális vektorának is szokás nevezni.

A görbületi vektor merőleges az érintőre, így az $\mathbf{n}(s)$ fönormális egységvektor is meröleges a $\mathbf{t}(s)$ egységnyi érintővektorra. Egy görbe akkor és csak akkor egy egyenes darabja, ha $\kappa(s) \equiv 0$.

A következö állítás alapján a görbületet ki lehet számítani a paraméterező függvény első és második deriváltjából.

1. Állítás. A $\gamma$ görbe görbülete tetszöleges paraméterezés esetén

$$
\kappa(t)=\frac{|\dot{\gamma}(t) \times \ddot{\gamma}(t)|}{|\dot{\gamma}(t)|^{3}} .
$$

Bizonyitás. Ha $s=s(t)$ jelöli görbe ívhosszát, akkor

$$
\dot{\gamma}(t)=\dot{\gamma}(s) \cdot s^{\prime}(t) \quad \text { és } \quad \ddot{\gamma}(t)=\ddot{\gamma}(s) \cdot\left(s^{\prime}(t)\right)^{2}+\dot{\gamma}(s) \cdot s^{\prime \prime}(t),
$$

így

$$
\frac{|\dot{\gamma}(t) \times \ddot{\gamma}(t)|}{|\dot{\gamma}(t)|^{3}}=\frac{|\dot{\gamma}(s) \times \ddot{\gamma}(s)| \cdot|s t(t)|^{3}}{|\dot{\gamma}(s)|^{3} \cdot|s \prime(t)|^{3}}=|\ddot{\gamma}(s)|=\kappa(s) .
$$

Érdekes alkalmazás a görbülethez kapcsolódóan a következö: a vasúti pályák esetén két eltérö, állandó görbületü pályaszakasz csatlakozásánál a gyorsulás, illetve a harmadrendü jellemző ugrásszerü változásának kiküszöbölésére az eltérő görbületü íveket egy, a pálya síkjában fekvő és fokozatos "görbületváltozást" biztosító közbenső görbületátmenettel, az úgynevezett átmeneti ívvel kötik össze. [5] 


\subsection{Torzió}

Amennyiben a $\gamma$ görbe valamely pontjában nem tünik el a görbület, akkor definiálni lehet a görbeív pontbeli simulósíkját és simulókörét is.

2. Definíció. ([4]) Legyen az ívhossz szerinti $\boldsymbol{\gamma}$ paraméterezésü görbe $\boldsymbol{\gamma}\left(\boldsymbol{s}_{\mathbf{0}}\right)$ pontjában $\boldsymbol{\kappa}\left(\boldsymbol{s}_{\mathbf{0}}\right) \neq \mathbf{0}$. Ha $\boldsymbol{s}_{1}, \boldsymbol{s}_{\mathbf{2}} \rightarrow \boldsymbol{s}_{\mathbf{0}}$ esetén a $\boldsymbol{\gamma}\left(\boldsymbol{s}_{1}\right), \boldsymbol{\gamma}\left(\boldsymbol{s}_{2}\right)$ és $\boldsymbol{\gamma}\left(\boldsymbol{s}_{\mathbf{0}}\right)$ kijelöl egy $\boldsymbol{S}\left(\boldsymbol{s}_{\mathbf{0}}, \boldsymbol{s}_{1}, \boldsymbol{s}_{2}\right)$ síkot, és ezeknek létezik határhelyzete, akkor azt a görbe $\boldsymbol{\gamma}\left(\boldsymbol{s}_{\mathbf{0}}\right)$-beli (vagy röviden $\boldsymbol{s}_{\mathbf{0}}$-beli) simulósíkjának nevezzük.

A következő tétel megadja a kapcsolatot az érintővektor és a fönormális vektor, illetve a simulósík között.

2. Tétel. ([4]) A $\boldsymbol{t}\left(\boldsymbol{s}_{\mathbf{0}}\right)$ és $\boldsymbol{n}\left(\boldsymbol{s}_{\mathbf{0}}\right)$ által kifeszitett sík éppen az $\boldsymbol{\gamma}\left(\boldsymbol{s}_{\mathbf{0}}\right)$-beli simulósík.

A fentiekhez hasonló elven vezethetö be a simulókör fogalma is.

3. Definíció. ([4]) Legyen az ívhossz szerinti $\gamma$ paraméterezésủ görbe $\gamma\left(\mathrm{s}_{0}\right)$ pontjában $\kappa\left(\mathrm{s}_{0}\right) \neq 0$. Ha $\mathrm{s}_{1}, \mathrm{~s}_{2} \rightarrow \mathrm{s}_{0}$ esetén a $\gamma\left(\mathrm{s}_{1}\right), \gamma\left(\mathrm{s}_{2}\right)$ és $\gamma\left(\mathrm{s}_{0}\right)$ pontokra illeszkedik egy $\mathrm{K}\left(\mathrm{s}_{0}, \mathrm{~s}_{1}, \mathrm{~s}_{2}\right)$ kör, és ezen köröknek létezik határhelyzete, akkor azt a görbe $\gamma\left(\mathrm{s}_{0}\right)$-beli (vagy röviden $\mathrm{s}_{0}$-beli) simulókörének nevezzük.

A simulókör mindig a simulósíkban van, érinti a görbe $\mathbf{t}$ érintőjét, továbbá a $\gamma\left(s_{0}\right)$ pontban a simulókör sugara

$$
\rho\left(s_{0}\right)=\frac{1}{\kappa\left(s_{0}\right)} .
$$

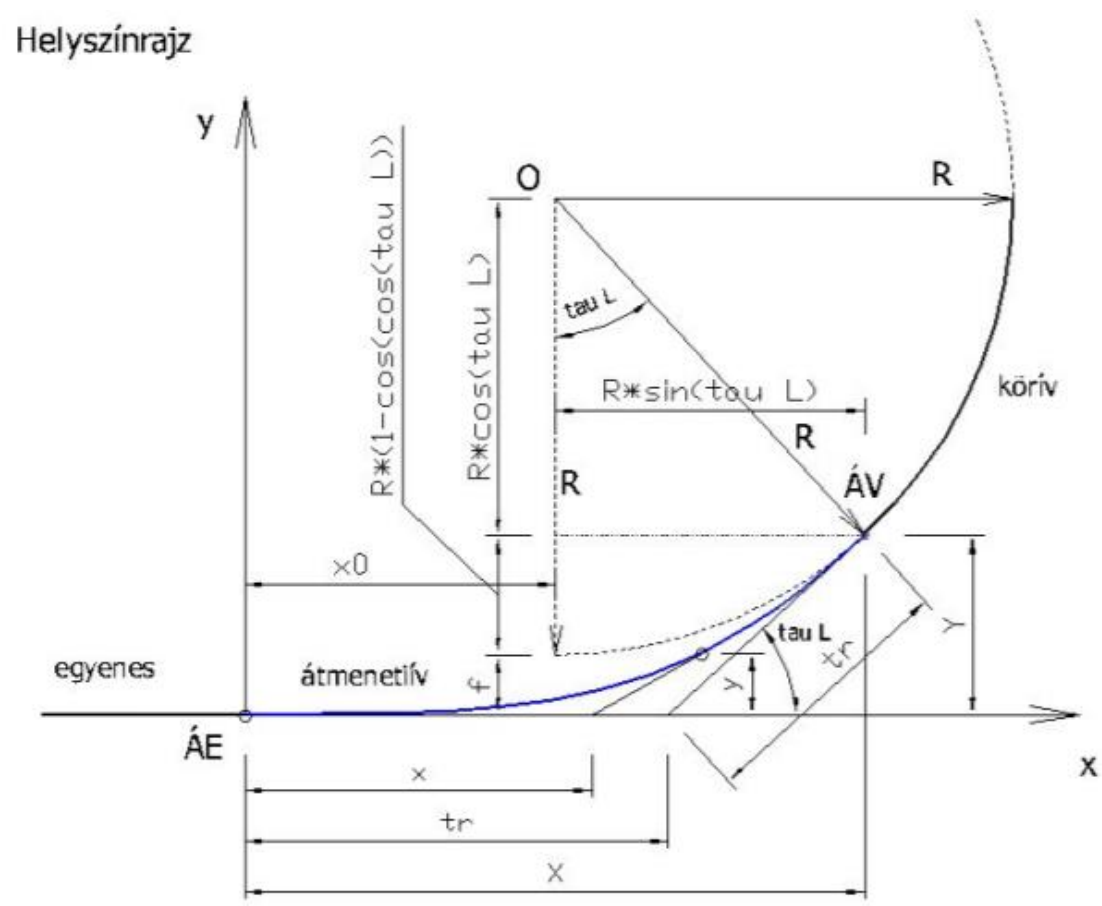

3. ábra. Az átmenetiív 
4. Definíció. A simulósík $\boldsymbol{b}(\boldsymbol{s})=\boldsymbol{t}(\boldsymbol{s}) \times \boldsymbol{n}(\boldsymbol{s})$ normálisát a görbe binormális vektorának nevezzük.

Könnyen belátható, hogy a binormális deriváltja párhuzamos a normálissal.

Ha a görbe görbülete sehol sem tünik el, akkor definiálhatjuk a görbe torzióját, amely azt méri, hogy a görbe mennyire csavarodik.

5. Definíció. A $\tau(s)=-\dot{\boldsymbol{b}}(s) \boldsymbol{n}(s)$ értéket a görbe $\gamma(s)$ pontban vett torziójának nevezzük.

Bizonyítható, hogy a torzió a görbe geometriai jellemzője, azaz független a görbe paraméterezésétöl, ugyanis a torzió a binormális forgásának szögsebessége a t tengely körül. Megjegyezzük, hogy egy görbe pontosan akkor síkgörbe, ha a torziója azonosan nulla.

A torzió szintén fontos szerepet tölt be a a vasútépítésben az átmenetívek tervezésénél.

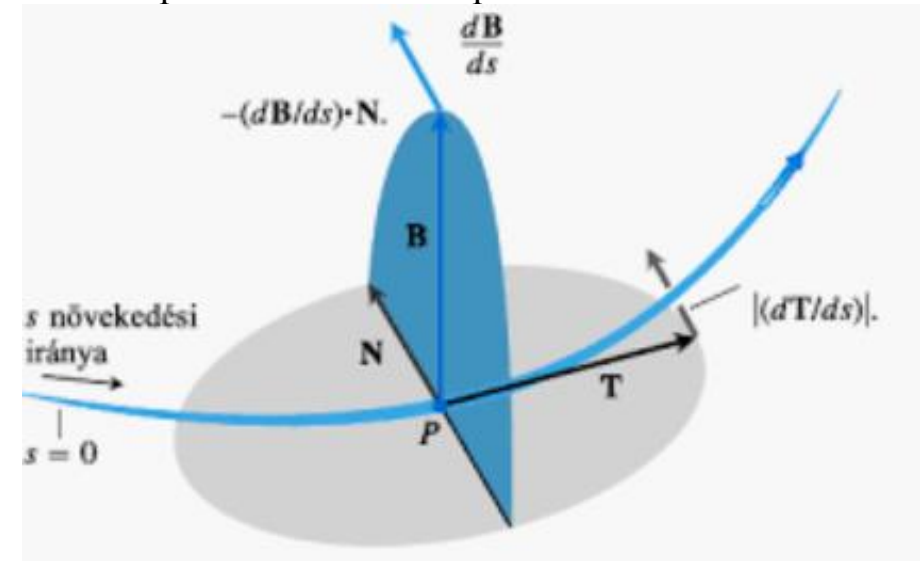

4. ábra. A torzió

\subsection{Kísérő triéder}

A $(\mathbf{t}, \mathbf{n}, \mathbf{b})$ érintő-, főnormális és binormális vektorok alkotta hármast szokás a görbe kísérö triéderének nevezni, melynek deriváltjai kifejezhetőek a görbület és a torzió segítségével:

3. Tétel. (Frenet-formulák).

$$
\begin{gathered}
\dot{\mathbf{t}}=\kappa \mathbf{n} \\
\dot{\mathbf{n}}=-\kappa \mathbf{t}+\tau \mathbf{b} \\
\dot{\mathbf{b}}=-\tau \mathbf{n}
\end{gathered}
$$

A Frenet-formulák felhasználásával a torzió felírható egy paraméterezésétől független alakban.

2. Állítás. A $\gamma$ görbe torziója tetszöleges paraméterezés esetén

$$
\tau(t)=\frac{\dot{\gamma}(t) \ddot{\gamma}(t) \dddot{\gamma}(t)}{|\dot{\gamma}(t) \times \ddot{\gamma}(t)|^{2}} .
$$

A Frenet-formulák felhasználásával igazolható a következő állítás, amely pongyolán fogalmazva azt 
jelenti, hogy a $\kappa(s)$ és a $\tau(s)$ egyértelműen meghatározza a térgörbe alakját, de térbeli helyzetét szabadon hagyja. [3]

3. Állítás. Két görbéhez akkor és csakis akkor létezik mozgás, mely öket egymásba viszi, ha ivhossz szerinti paraméterezésben a görbület és a torzió a két görbén azonosan egyenlö.

A görbeelmélet alaptétele az unicitás mellett az egzisztenciára vonatkozó állítást is megfogalmaz:

4. Tétel. ([7]) Egy $I \subset \mathbb{R}$ intervallumon legyenek adva a $\boldsymbol{C}^{\infty}$-osztályú

$$
\kappa, \tau: I \rightarrow \mathbb{R}
$$

függvények. Amennyiben $\kappa>0$ teljesül, akkor irányitástartó izometria erejéig pontosan egy olyan ivhossz szerint paraméterezett $\gamma: I \rightarrow \mathbb{R}^{3}$ valódi görbe létezik, amelynek $\kappa$ a görbületi függvénye és $\kappa$ a torzió függvénye.

A görbület és a csavarodás tehát a koordináta-rendszertől függetlenül határozza meg a görbét, így a

$$
\kappa=\kappa(s) \quad \text { és } \quad \tau=\tau(s)
$$

egyenleteket a görbe természetes egyenleteinek, a $\kappa$-t és a $\tau$-t a görbe természetes koordinátáinak nevezzük.

Példa. $A \gamma(t)=$ acoste $_{1}+$ asinte $_{2}+$ bte $\boldsymbol{e}_{3}$ közönséges csavarvonal természetes egyenletei:

$$
\kappa=\frac{a}{a^{2}+b^{2}} \quad \text { és } \quad \tau=\frac{b}{a^{2}+b^{2}} .
$$

A $\kappa=0$ esetben a csavarvonal egyenessé, a $\tau=0$ esetben pedig körré fajul.

Megjegyezzük, hogy egy térgörbe pontosan akkor tolható el önmagába, két tetszőleges pontját fedésbe hozva, ha a görbülete és a torziója konstans, amely kritériumnak csak a közönséges csavarvonal felel meg.

\section{Felületek}

A körülöttünk lévő világban számos olyan objektum van, amelyre a felület megnevezést használjuk. Ezen felületek matematikai modelljének megadása gyakorlati szempontból fontos, például a felület felszínének meghatározásához, számítógépes grafikai alkalmazásához, mérnöki számítások elvégzéséhez.

A felületelméletből a felületek paraméteres megadását emeljük ki, majd példát adunk felületi görbére. Megemlítjük, hogy az első alapmennyiségek fogalma, a felületi görbék ívhossza, görbülete, a felületek felszínének kiszámítása, valamint a felületi integrálok tartoztak még az oktatott témakörhöz.

\subsection{Felületek paraméteres megadása}

Legyen $D \subset \mathbb{R}^{2}$ nem üres nyílt halmaz. Egy $\mathbf{r}: D \rightarrow \mathbb{R}^{3}$ differenciálható leképezés esetén állapodjunk meg a következő jelölésekben: a változókat jelölje $u$ és $v$, a komponensfüggvényeket pedig $x, y$, illetve $z$, azaz

$$
r(u ; v)=(x(u ; v) ; y(u ; v) ; z(u ; v)) .
$$

A $\mathbf{r}$ első és második változó szerinti parciális deriváltjait jelölje $\mathbf{r}_{u}$ és $\mathbf{r}_{v}$. 
Azt mondjuk, hogy a $\mathbf{r}: D \rightarrow \mathbb{R}^{3} C^{\infty}$-osztályú leképezés egy sima elemi felület paraméterezése, ha teljesül rá az alábbi két feltétel:

- Bármely $p \in D$ esetén az $\mathbf{r}_{u}(p)$ és $\mathbf{r}_{v}(p)$ vektorok lineárisan függetlenek.

- Az $\mathbf{r}$ vektorfüggvény injektív, továbbá egy homeomorfizmust ad a $D$ tartomány és az $\mathbb{R}^{3}$-beli $\mathbf{r}(U)$ alakzat között, azaz invertálható és az inverze is folytonos.

Az $\mathbb{R}^{3}$ tér egy $M$ alakzatát sima elemi felületnek nevezzük, ha megadható egy olyan előzö feltételeket kielégítő $\mathbf{r}: D \subset \mathbb{R}^{2} \rightarrow \mathbb{R}^{3}$, ahol $\mathbf{r}(D)=M$. Az $\mathbf{r}=\mathbf{r}(u ; v)$ egyenletet a felület paraméteres egyenletének, a koordinátákra bontott

$$
x=x(u ; v), \quad y=y(u ; v), \quad z=z(u ; v)
$$

alakját pedig a felület paraméteres egyenletrendszerének nevezzük.

A továbbiakban sima elemi felületeket röviden felületnek nevezzük majd, de megjegyezzük, hogy "felület" alatt általánosságban nem feltétlenül sima elemi felületet szokás érteni, hanem egy olyan összefüggő térbeli ponthalmazt, melynek minden pontja rendelkezik olyan gömbkörnyezettel, melyben a ponthalmaz elmei felület. [4]

Példa. Írjuk fel az

$$
\mathbf{r}(u ; v)=u \cos v \mathbf{i}+u \sin v \mathbf{j}+v \mathbf{k}
$$

paraméteres alakban adott felület implicit egyenletét! Mi ez a felület?

Mivel

$$
x=u \cos v, \quad y=u \sin v \text { és } v=z,
$$

visszahelyettesítve és rendezve egy csavarfelület egyenletét kapjuk:

$$
x \sin z=y \cos z \text {. }
$$

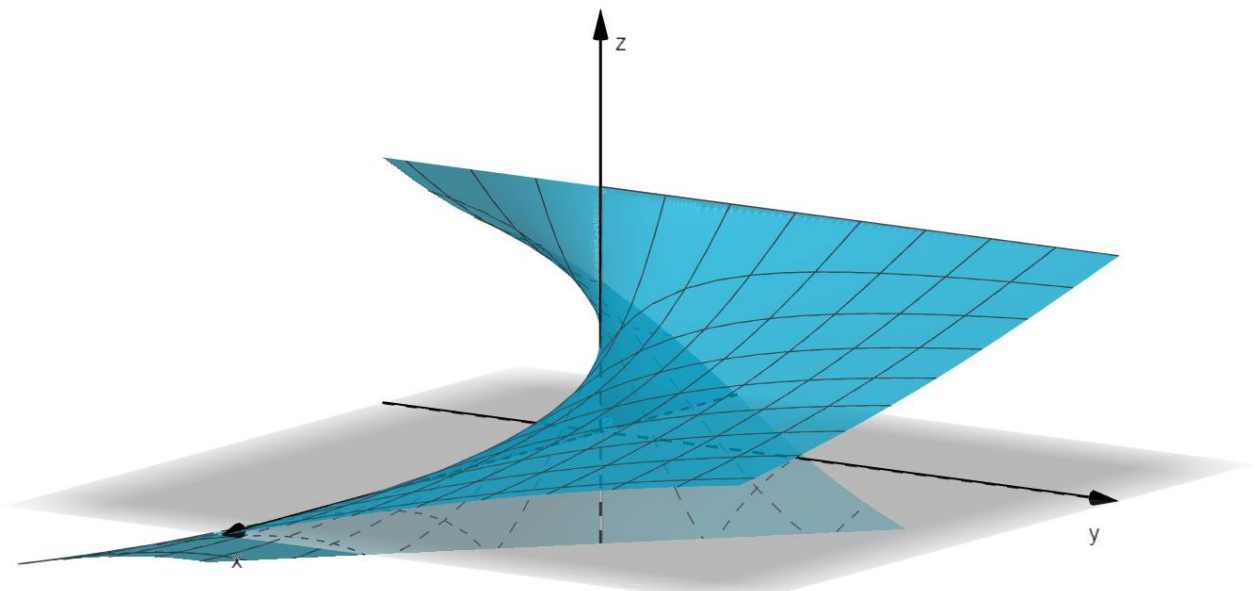

\section{5. ábra. Csavarfelület}


Ha egy görbét úgy mozgatunk a térben, hogy minden pontja azonos tengelyü és menetmagasságú csavarvonalat ír le, akkor görbe pontjai csavarfelületet alkotnak. Csavarfelületekkel a müszaki gyakorlatban gyakran találkozhatunk; például csigafúrók, ferdefogú fogaskerekek, csigakerekek, csavarok esetén.

Ha $z$ a forgástengely, $f(u)$ a csavarfelület profilgörbéje, az $A$ pedig a haladó mozgás sebességének és a szögsebességnek az aránya, akkor a csavarfelület egyenlete:

$$
\mathbf{r}(u ; v)=(u \cos v ; u \sin v ; f(u)+A v) .
$$

Egyenes csavarvonal esetén vonalfelületet kapunk, a $v$ szerinti paramétervonalak a tengelyre meröleges egyenesek, a csavarfelületek egyenlete ebben az esetben:

$$
\mathbf{r}(u ; v)=(u \cos v ; u \sin v ; A v),
$$

azaz az előző példában szereplő csavarvonal egyenes csavarvonal, amelynél a haladó mozgás sebessége és a szögsebesség megegyezik.

Példa. [6] Bizonyítsuk be, hogy az alábbi két egyenletrendszer ugyanazt a felületet írja le!

$$
\begin{gathered}
x=\frac{u}{u^{2}+v^{2}} \quad y=\frac{v}{u^{2}+v^{2}} \quad z=\frac{1}{u^{2}+v^{2}} \\
x=u \cos v \quad y=u \sin v \quad z=u^{2}
\end{gathered}
$$

Mi ez a felület?

A két paraméterezés által adott felületek egybeesését a paraméterek kiküszöbölésével igazolhatjuk. Az első paraméterezés esetén:

$$
x=u z, \quad y=v z \Rightarrow u=\frac{x}{z}, \quad v=\frac{y}{z} .
$$

Behelyettesítve $u$-t és $v$-t a $z=\frac{1}{u^{2}+v^{2}}$ egyenletbe a felület egyenlete:

$$
z=x^{2}+y^{2} \text {. }
$$

A második paraméterezés esetén:

$$
x^{2}=u^{2} \cos ^{2} v \quad y^{2}=u^{2} \sin ^{2} v \Rightarrow z=x^{2}+y^{2} .
$$

A két implicit alak megegyezik, ezért a két felület is ugyanaz, mégpedig egy forgásparaboloid.

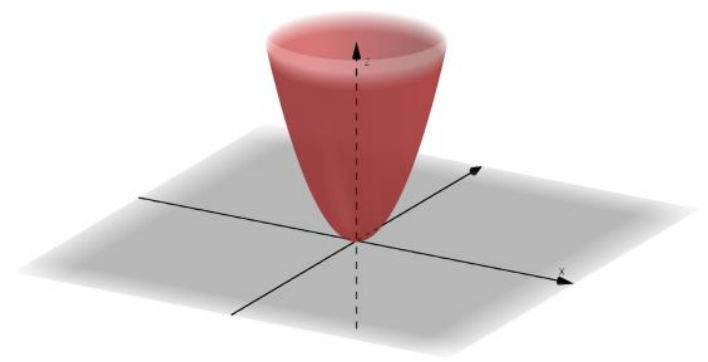

6. ábra. Forgásparaboloid 


\subsection{Felületi görbék}

Egy $C^{\infty}$-osztályú $\gamma: I \rightarrow \mathbb{R}^{3}$ leképezést az $\mathrm{M}$ egy sima felületi görbéjének nevezünk, ha a görbe pályája rajta van az $\mathrm{M}$ felületen.

Példa. Igazoljuk, hogy az alábbi térgörbe egy origó középpontú gömb felületi görbéje!

$$
\gamma(t)=\left(\cos t \sin t ; \sin ^{2} t ; \cos t\right)
$$

Mivel

$$
\cos ^{2} t \sin ^{2} t+\sin ^{4} t+\cos ^{2} t=\sin ^{2} t+\cos ^{2} t=1,
$$

így a görbe az origó középpontú 1 sugarú gömb felületi görbéje.

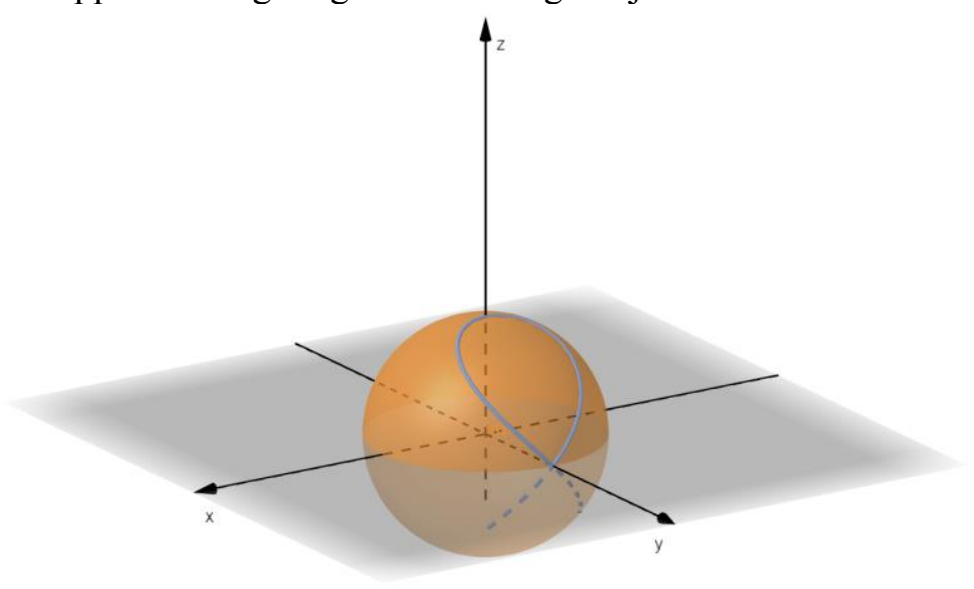

7. ábra. Gömb felületi görbéje

Igazolható, hogy minden felületi görbe reguláris. Teljesül továbbá, hogy egy parametrizált felület egy adott pontján áthaladó felületi görbék ezen pontbeli érintővektorai az adott pontbeli érintősíkban vannak, valamint, hogy a felület minden érintővektora valamely felületi görbe érintője.

\section{4. Összefoglalás}

Cikkünkben a hagyományos egyetemi képzésben oktatott görbe- és felületelméletböl idéztünk fel néhány alapvető fogalmat, amelyek a müszaki alkalmazások szempontjából különös jelentőséggel bírtak. A differenciálgeometria alkalmazása azonban napjaink technológia-vezérelt világában is megjelenik, gondolhatunk itt többek között a gépi látásra, a számítógépi grafikára, az orvosi képalkotó (CT, MRI, PET, SPECT) rendszerekre, a digitális jelfeldolgozásra vagy például a nemlineáris szabályozáselmélet modern irányzatára. A fentiek alapján a differenciálgeometria elemeinek megjelenése a mesterképzésben, mind a müszaki, mind az informatikai képzési területen - például szabadon választható tárgy formájában - indokolt. 


\section{Irodalom}

[1] Manfredo P. do Carmo: Differential geometry of curves and surfaces, Prentice-Hall Inc., Englewood Cliffs, N.J., 1976.

[2] Gu X., Wang Y., Cheng HB., Cheng LT., Yau ST. Geometric Methods in Engineering Applications. In: Munthe-Kaas H., Owren B. (eds) Mathematics and Computation, a Contemporary View. Abel Symposia, vol 3. Springer, Berlin, Heidelberg, 2008.

[3] Fazekas Ferenc: Müszaki matematikai gyakorlatok B. I-III., Vektoranalízis - Térgörbék és felületek differenciálgeometriája, skalár-, vekor és tenzorterek, Tankönyvkiadó Vállalat, Budapest, 1957.

[4] Kurusa Árpád: Bevezetés a differenciálgeometriába, Polygon, Szeged, 1999., ISSN 1417-0590

[5] Liegner Nándor: Vasúti görbület-átmeneti geometriák és alkalmazásuk, BME, Budapest, 2004.

[6] Szilágyi Brigitta: Differenciálgeometria példatár, Typotex Kiadó, Budapest, 2011., ISBN: 978963-279-449-5

[7] Verhóczki László: Klasszikus differenciálgeometria, ELTE TTK, Budapest, 2013. Elektronikus jegyzet: http://web.cs.elte.hu/geometry/vl/KlasszDiffGeo.pdf 